\title{
AMMONIA REMOVAL FROM SEWAGE WASTEWATER USING CHEMICALLY MODIFIED SAND
}

\author{
HALIM, A. A. - HANAFIAH, M. M. ${ }^{*}$ - KHAIRI, A. \\ School of Environmental and Natural Resource Sciences, Faculty of Science and Technology, \\ Universiti Kebangsaan Malaysia, 43600 UKM Bangi, Selangor, Malaysia \\ *Corresponding author \\ e-mail: mhmarlia@ukm.edu.my; phone:+60-389-215-865; fax:+60-389-253-357
}

(Received 22 $2^{\text {nd }}$ Jul 2016; accepted $9^{\text {th }}$ Nov 2016)

\begin{abstract}
The study was conducted to observe the effectiveness and the efficiency of the adsorption method to remove ammonia from sewage water. The experimental design involves fixed-bed column, desorption and regeneration study. The results showed that the modified sand performed better in removing ammonia from sewage compared with pristine sand and regenerated used modified sand. The experimental data showed a better fit to the Thomas and Yoon-Nelson adsorption models. We found that the modified sand removed ammonia up to $99 \%$ and remained $80 \%$ of removal after 50 minutes compared to the pristine sand that was only $78.51 \%$ and gradually dropped to $10 \%$ after 50 minutes. Modified sand recorded the maximum adsorption capacity of $0.014 \mathrm{mg} / \mathrm{g}$ compared to $0.0033 \mathrm{mg} / \mathrm{g}$ for pristine sand and $0.0087 \mathrm{mg} / \mathrm{g}$ for regenerated used modified sand. Modified sand was able to be reused using a relatively low cost regenerating solution $(\mathrm{NaCl})$.
\end{abstract}

Keywords: fixed bed adsorption, wastewater treatment, nitrogen, X-ray diffraction, column experiment, regeneration

\section{Introduction}

Nitrogen compounds such as ammonia, nitrite and nitrate are often present in wastewater and can end up in lakes, rivers and drinking water reservoirs (AWWA, 1990). In many developed countries, consent levels for the amount of ammonium contained in the final effluent invariably dictates the need for a nitrogen treatment step to be included as part of the wastewater treatment process (Pearce et al., 2000). Ammonia removal from water and wastewater is vital especially in environmental protection as ammonia can lead to problems such as eutrophication, corrosion and fouling (Rožić et al., 2000).

Various conventional methods are capable of removing ammonia from aqueous solutions, which include air stripping, breakpoint chlorination, ion exchange and biological nitrification-denitrification. Adsorption using various types of adsorbents is an important method due to its ease of operation and relatively low cost. Various studies to remove ammonia in water by adsorption methods have been carried out (Rožić et al., 2000; Halim et al., 2012; Aziz et al., 2004; Lei et al., 2008; Halim et al., 2010; Sarioglu, 2005). Among them are clay and zeolite (Rožić et al., 2000; Sarioglu, 2005; Celik et al., 2001), limestone (Aziz et al., 2004), carbon-zeolite composite (Halim et al., 2009) and silica-carbon-calcium carbonate (Aguilar et al., 2002). This study was done to modify silica sand as an alternative adsorbent which is of lower cost than other conventional adsorbents.

The application of sand in water treatment has been reported previously (Ehret et al., 2001). It has been used to filter particulate matter and to reduce turbidity. Sand as a filter was also used to remove bacteria (Ellis and Wood, 1985; Ellis, 1987). A previous study found that sand modified with aluminum hydroxide was able to filter 
microorganism effectively (Farrah and Preston, 1985). Sand surface coated with ferric oxide is capable of removing uncomplexed and ammonia-complexed cationic metals (copper, cadmium, lead, nickel and zinc) as well as some oxyanionic metals $\left(\mathrm{SeO}_{3}\right.$ and $\mathrm{AsO}_{3}$ ) from simulated and actual waste streams over a wide range of metal concentrations (Benjamin et al., 1996). The adsorbent was stable during backwashing and regeneration operations, releasing most metals quantitatively. This composite media is inexpensive, easy to prepare and can serve as the basis of a useful metal removal and possibly metal recovery process in a variety of settings.

Therefore, the aim of this study was to investigate the fixed bed adsorption capability of both chemically modified sand and pristine sand to remove ammonia from sewage wastewater. In addition, this study reported the regeneration and desorption processes for identifying the ability of chemically modified sand to be reused.

\section{Research methods}

\section{Modification of sand surface}

Commercial sand with the size in the range of 0.5-1.0 mm was used in this study. The modification of the sand surface was done using sodium aluminates $\left(\mathrm{NaAlO}_{2}\right)$ and sodium hydroxide $(\mathrm{NaOH})$. The sand was washed with distilled water before soaking into the chemical solution. The optimum concentration ratios of $\mathrm{NaAlO}_{2}$ over $\mathrm{NaOH}$ were determined in various concentration of $\mathrm{NaAlO}_{2}(0.125 \mathrm{M}, 0.25 \mathrm{M}, 0.5 \mathrm{M}, 1.0 \mathrm{M}$, $2.0 \mathrm{M}$ and $3.0 \mathrm{M}$ ) and fixed concentration of $\mathrm{NaOH}(4 \mathrm{M})$. Then, the sand was soaked in this chemical solution and heated at $80^{\circ} \mathrm{C}$ for 30 minutes. A sufficient solution was poured to completely cover the sand. The sand was left overnight, rinsed and stored at room temperature.

\section{X-Ray Diffraction (X-RD)}

This test was done using an X-ray diffraction spectrometer (model D-5000, Siemens, Germany). The purpose of this test was to determine the mineral content present in the new chemically modified sand adsorbent.

\section{Column adsorption study}

Columns were made of Perspex with a dimension of $80 \mathrm{~cm}$ height and $10 \mathrm{~cm}$ internal diameter. Modified and pristine sand was packed in columns. The weight of adsorbent added was $996 \mathrm{~g}$ with a measured volume of $700 \mathrm{~mL}$. Before being used, deionized water was passed through the columns to ensure the column effluents were clear and free of precipitates. A Masterflex peristaltic pump was employed to feed the stock solution to the column at $20 \mathrm{~mL} / \mathrm{min}$ of flow rate. Fixed bed column adsorption experiment was perform at $\mathrm{pH} 7$ as suggested by a previous researcher, which was the optimum $\mathrm{pH}$ for ammonia adsorption (Halim et al., 2011). Samples were collected at various time intervals and analyzed for ammoniacal nitrogen using the Nesslerization colorimetric method (APHA, 1995).

\section{Regeneration study}

The exhausted column was subjected to desorption to regenerate the adsorbent using a $1.0 \mathrm{M} \mathrm{NaCl}$ solution at $\mathrm{pH} 12$ (adjusted using sodium hydroxide) (Celik et al., 2001). 
To regenerate the column, $\mathrm{NaCl}$ was pumped through the adsorbent in the up flow mode and the breakthrough solution was collected for determination of ammonia content.

\section{Results and discussion}

\section{$X-R a y$ Diffraction $(X-R D)$}

From the X-RD test (Fig.1), the obvious change of spectra was obtained for microline minerals, $\mathrm{Na}^{+}\left[\mathrm{AlSi}_{3} \mathrm{O}_{8}\right]^{-}$, which was detected at $2 \theta=27.48$. The presence of this mineral may increase the number of cation exchange sites, thus increasing the cation exchange capacity during wastewater treatment.

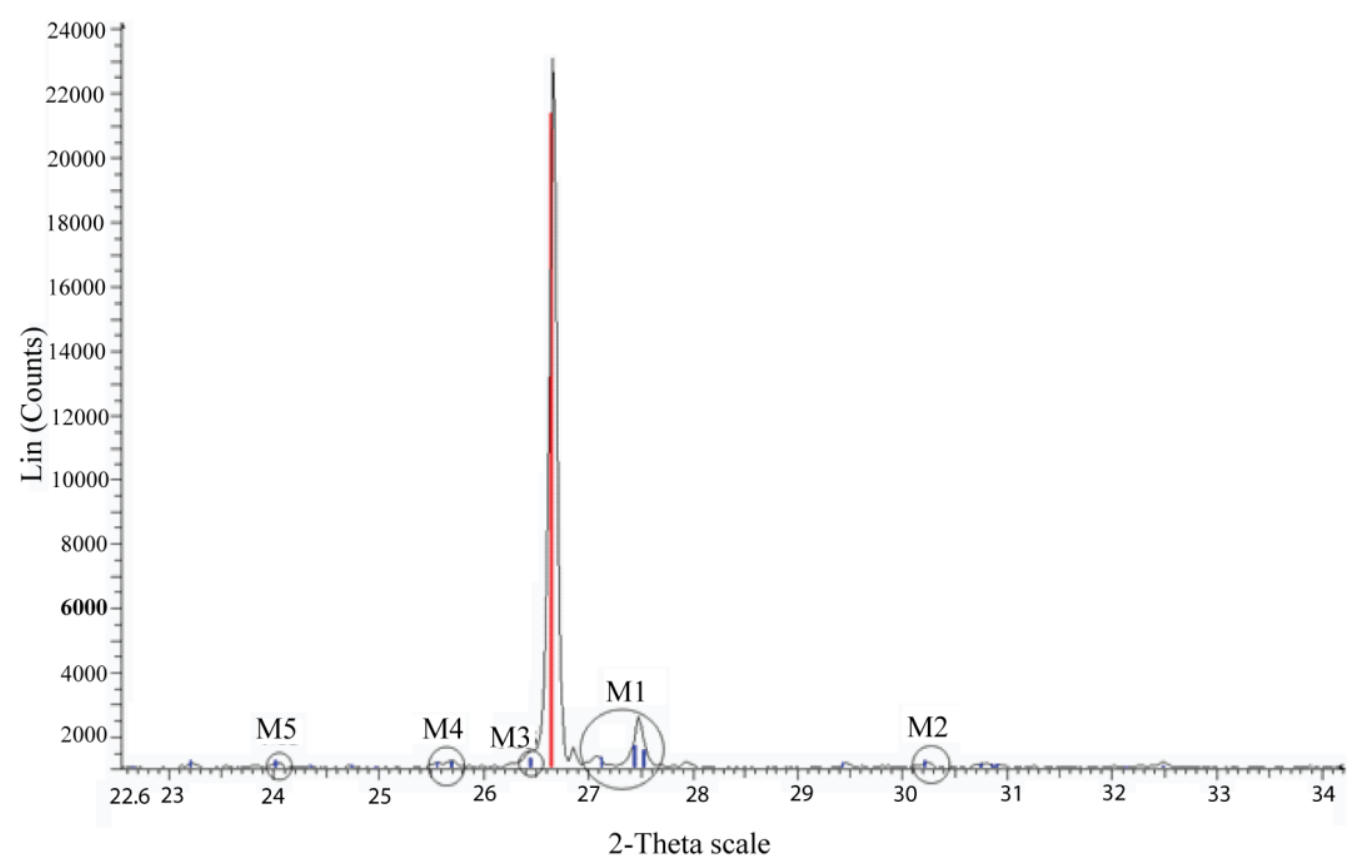

Figure 1. X-ray diffraction spectra for chemically modified sand

\section{Fixed bed adsorption}

As indicated in Fig. 2, ammonia removal was more successful by using chemically modified sand. The modified sand removed ammonia up to $99 \%$ and remained $80 \%$ of removal after 50 minutes. Maximum removal of ammonia by pristine sand was only $78.51 \%$ and gradually dropped to $10 \%$ after 50 minutes. A statistical test (MannWhitney) found that $(\mathrm{P}<0.05)$ there was a significant difference in the rate of adsorption for both types of adsorbents. The regenerated modified sand also performed well as the removal percentage of ammonia was more than $80 \%$.

Ammonia adsorption activity is based on the ion-exchange process of $\mathrm{Na}^{+}>\mathrm{K}^{+}>\mathrm{Ca}^{2+}>\mathrm{Mg}^{2+}$ where $\mathrm{Na}^{+}$has higher affinity towards ion exchange with ammonia compared with other cations. The process of ion exchange involves replacement of ions on the solid phase with the ions from the liquid phase (Lei, 2008). The reaction occurred can be represented by the equation 1 :

$$
S-\mathrm{Na}^{+}(\mathrm{s})+\mathrm{NH}_{4}^{+}(\mathrm{aq}) \longleftrightarrow \mathrm{Na}^{+}(\mathrm{aq})+S-\mathrm{NH}_{4}^{+}(\mathrm{s})
$$


Where, $S$ refers to the sand surface. The ammonium desorption process for used modified sand was perform using $1.0 \mathrm{M} \mathrm{NaCl}$ at $\mathrm{pH} 12$ (adjusted using $\mathrm{NaOH}$, at flow rate $10 \mathrm{ml} / \mathrm{min}$ ) as shown in Fig. 3. Desorption process was almost complete at 2.91 of bed volume.

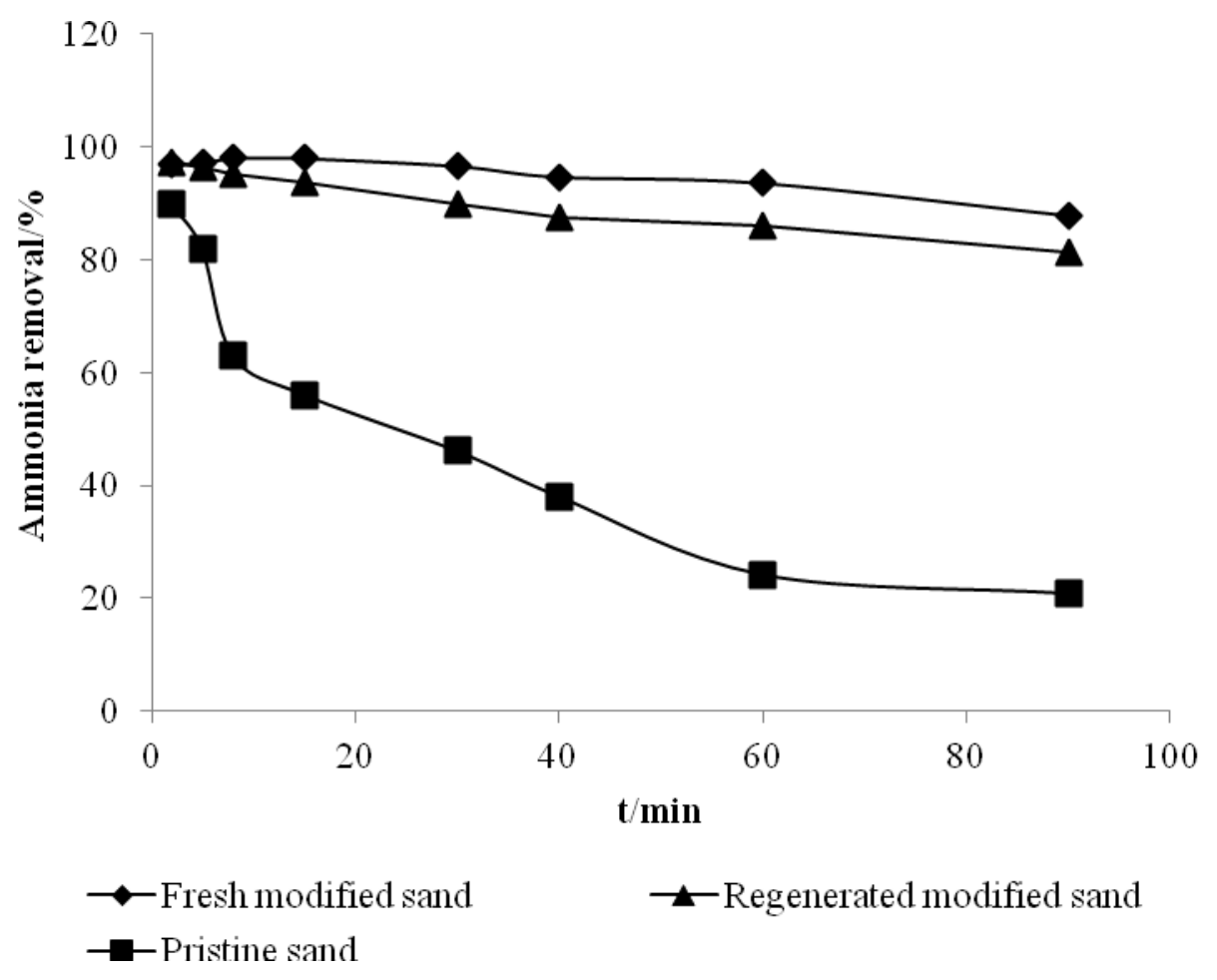

Figure 2. Comparison of pristine sand with fresh modified sand and regenerated modified sand (regenerated from used modified sand) in term of ammonia removal in column adsorption study

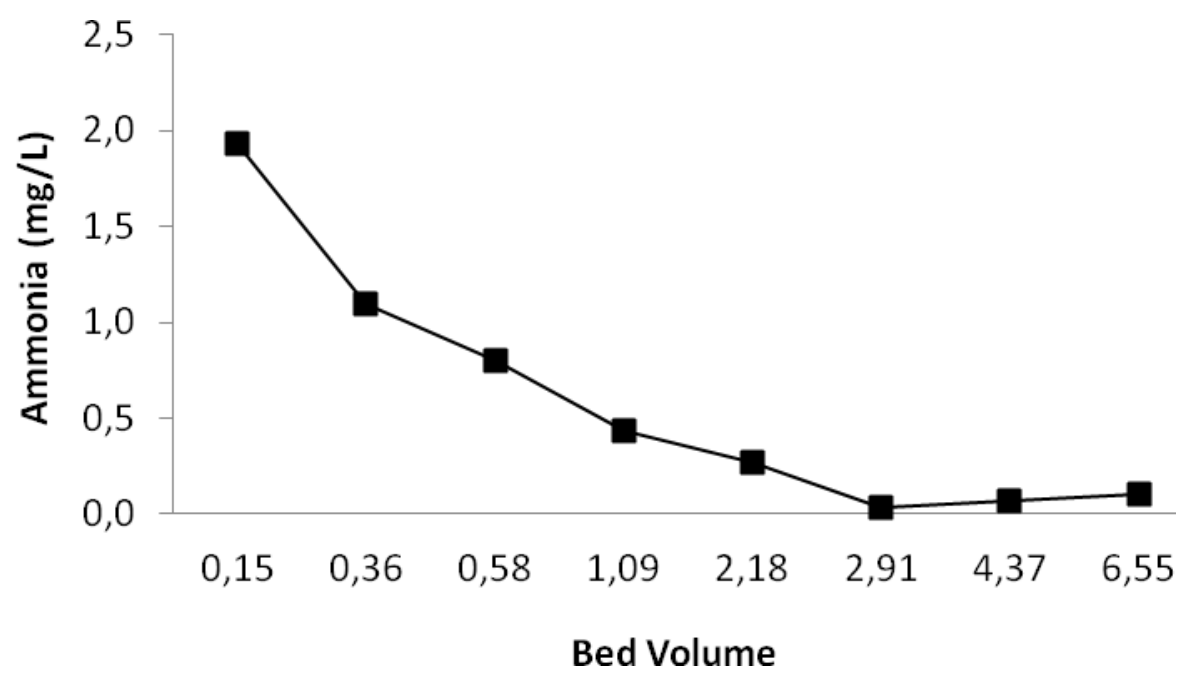

Figure 3. Ammonia desorption from used modified sand vs. bed volume of a $1.0 \mathrm{M} \mathrm{NaCl}$ solution at pH 12 (adjusted using sodium hydroxide) at $10 \mathrm{ml} / \mathrm{min}$ flow rate 


\section{Modeling of fixed bed column adsorption}

Thomas and Yoon-Nelson mathematical models were applied in this study for evaluation of efficiency and applicability of column models for a large-scale operation (Thomas, 1944; Yoon and Nelson, 1984). Thomas model was adapted from the first order of the kinetic adsorption model. It can be expressed by the equation 2 below:

$$
\ln \left(\frac{C_{0}}{c_{\mathrm{t}}}-1\right)=\frac{k_{T} q_{o} m_{C}}{Q}-k_{T} C_{o} t
$$

Where $k_{T}(\mathrm{~mL} / \mathrm{min} \mathrm{mg})$ is the Thomas rate constant, $q_{o}(\mathrm{mg} / \mathrm{g})$ is the maximum capacity of ammonia adsorption; $C_{o}(\mathrm{mg} / \mathrm{L})$ is the initial concentration of ammonia in the sewage; $C_{t}(\mathrm{mg} / \mathrm{L})$ is the concentration of ammonia adsorption at the end of time $t$; $Q(\mathrm{~mL} / \mathrm{min})$ is the flow rate of solution, $m_{c}$ is the weight of adsorbent $(\mathrm{g})$ and $t$ is time (min). Linear graph was plotted to identify the values of $k_{T}$ and $q_{o}$ as shown in Fig. $4 \mathrm{~A}$ and Fig. 4C. As shown in Table 1, the value of $q_{o}$ for modified sand is higher than the untreated sand. Modified sand showed the maximum adsorption capacity of $0.014 \mathrm{mg} / \mathrm{g}$ compared with $0.0033 \mathrm{mg} / \mathrm{g}$ for pristine sand.
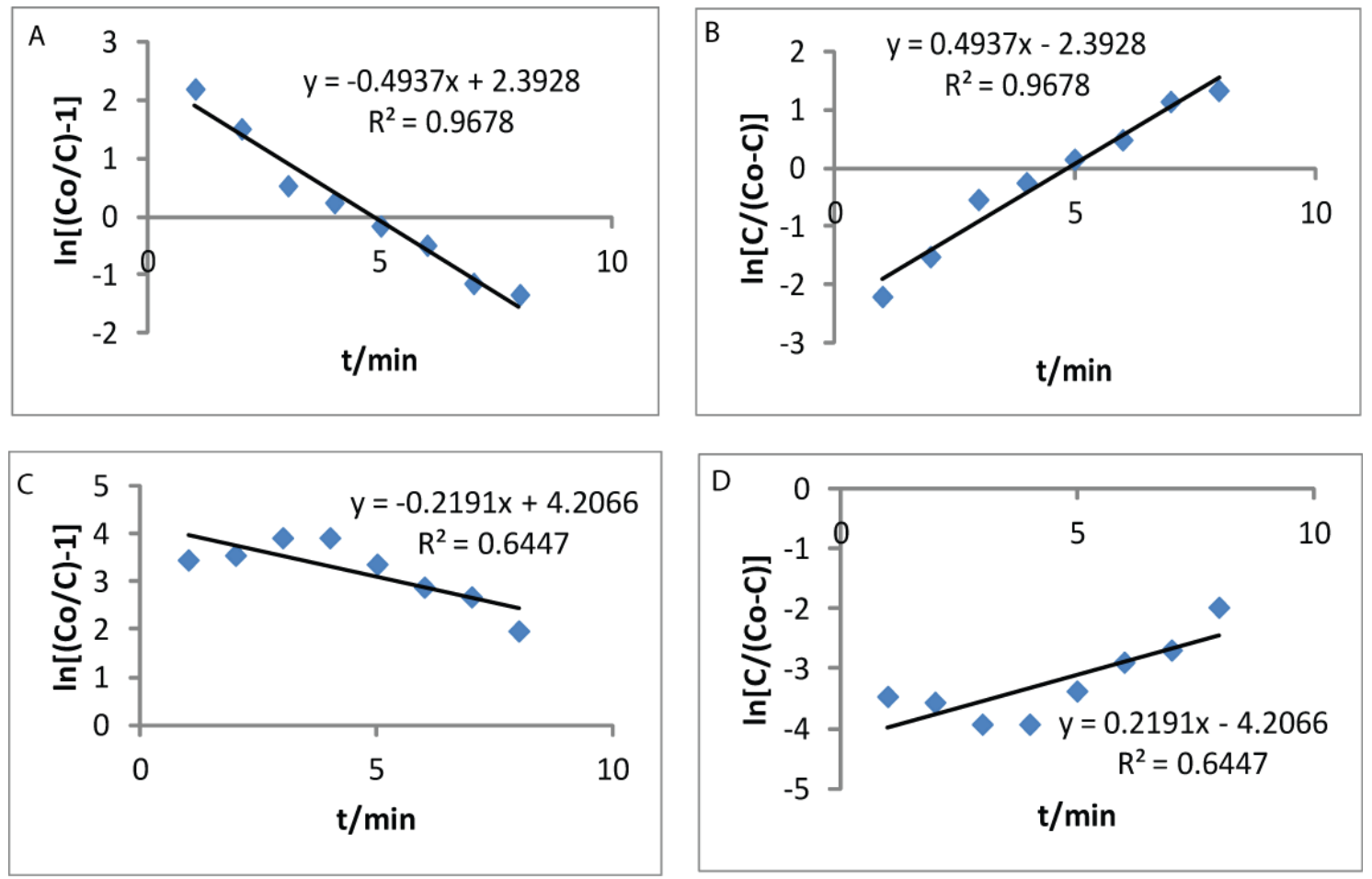

Figure 4. Fixed bed column adsorption modeling for pristine sand ( $A$ and $B$ ) and modified sand $(C$ and $D)$ using Thomas equation ( $A$ and $C$ ) and Yoon-Nelson equation ( $B$ and $D$ )

Table 1. Maximum adsorption capacity

\begin{tabular}{lccc}
\hline \multicolumn{1}{c}{ Sand } & $\begin{array}{c}\mathbf{k}_{\mathbf{T}} \\
(\mathbf{m L} / \mathbf{m g} / \mathbf{m i n})\end{array}$ & $\mathbf{R}^{\mathbf{2}}$ & $\begin{array}{c}\mathbf{q}_{\mathbf{o}} \\
(\mathbf{m g} / \mathbf{g})\end{array}$ \\
\hline Pristine sand & 0.0411 & 0.9675 & 0.0033 \\
Modified sand & 0.0183 & 0.6442 & 0.014 \\
Regenerated used modified sand & 0.0252 & 0.988 & 0.0087 \\
\hline
\end{tabular}


Principally, Yoon and Nelson model was used to estimate the possible decrease of adsorption rate, which is directly proportional to its adsorption action. This model can be expressed by the equation 3 :

$$
\ln \frac{c}{c_{0}-c}=k_{Y N} t-t_{0.5} k_{Y N}
$$

Where, $k_{Y N}(\mathrm{~L} / \mathrm{min})$ is the rate constant and $t_{0.5}(\mathrm{~min})$ is the breakthrough curve for 50 $\%$ of ammonia being absorbed by adsorbent. A plot of $\ln C /\left(C_{o^{-}} C\right)$ versus $t$ gives a straight line with a slope of $k_{Y N}$ and intercept of $t_{0.5} k_{Y N}$ as shown in Fig. $4 B$ and Fig. 4D. Based on Table 2, the values of breakthrough for $50 \%$ of ammonia absorbed by modified sand and pristine sand were 59.56 and $24.11 \mathrm{~min}$, respectively. For a given bed, the adsorption capacity of Yoon-Nelson model $\left(q_{o Y N}\right)$ for a given weight of adsorbent can be calculated using the equation 4 (Sivakumar and Palanisamy, 2009):

$$
q_{O Y N}=\frac{c_{0} Q t_{0.5}}{1000 \mathrm{X}}
$$

Based on Yoon-Nelson model, adsorption capacity, $q_{o Y N}$ of modified sand had increased to $0.014 \mathrm{mg} / \mathrm{g}$ compared to $0.03 \mathrm{mg} / \mathrm{g}$ for pristine sand.

\begin{tabular}{|c|c|c|c|c|}
\hline Adsorbent & $\begin{array}{c}k_{Y N} \\
(t / m i n)\end{array}$ & $\overline{\mathbf{R}^{2}}$ & $\begin{array}{c}\mathbf{t}_{0.5} \\
(\mathbf{m i n})\end{array}$ & $\underset{(\mathrm{mg} / \mathrm{g})}{\mathrm{q}_{\mathrm{oYN}}}$ \\
\hline Pristine sand & 0.4933 & 0.9678 & 4.85 & 0.0033 \\
\hline Modified sand & 0.2191 & 0.6447 & 20.54 & 0.0141 \\
\hline $\begin{array}{l}\text { Regenerated } \\
\text { used modified sand }\end{array}$ & 0.303 & 0.9885 & 12.75 & 0.0087 \\
\hline
\end{tabular}

Table 2. Adsorption capacity

\section{Regeneration}

The ability of modified sand to be reused was determined by regeneration or desorption studies. The result from the first desorption at flow rate $10 \mathrm{~mL} / \mathrm{min}$ using 1.0 $\mathrm{M} \mathrm{NaCl}$ at $\mathrm{pH} 12.3$ indicated that 2.91 BV (bed volume) of $\mathrm{NaCl}$ solution was sufficient for ammonium elution from used modified sand. Increasing flow rate needed a higher volume of regenerating solution to remove ammonium from modified sand surfaces. The reaction occurred on the sand surface between $\mathrm{Na}^{+}$(from $\mathrm{NaCl}$ solution) and ammonium can be summarized by the following ion exchange process:

$$
S-\mathrm{NH}_{4}^{+}+\mathrm{Na}^{+} \leftrightarrow \text { Sand }-\mathrm{Na}^{+}+\mathrm{NH}_{4}^{+}
$$

Desorption process was performed in alkali condition $(\mathrm{pH}=12.3)$ to convert ammonium ion to ammonia as shown in the equation 6:

$$
\mathrm{NH}_{4}^{+}+\mathrm{OH}^{-} \leftrightarrow \mathrm{NH}_{3}+\mathrm{H}_{2} \mathrm{O}
$$

Maximum adsorption capacity, $q_{o}$ for regenerated modified sand was slightly lower than fresh modified sand as indicated in Table 1. This indicated that by using $\mathrm{NaCl}$ 
solution, the regeneration of the column could be done repeatedly without loss of ammonium adsorption capacity.

\section{Conclusions}

Modified sand performed better in removing ammonia from sewage compared with pristine sand. The experimental data showed a better fit to the Thomas and YoonNelson adsorption models. Hence, these models can be used to describe the behaviour of the adsorption of ammonia in a continuous column. Modified sand was able to be reused using a relatively low cost regenerating solution $(\mathrm{NaCl})$.

Acknowledgements. Marlia Mohd Hanafiah was financed by research grants: FRGS/2/2013/STWN01/UKM/03/1 and TD-2014-012.

\section{REFERENCES}

[1] Aguilar, M. I., Sáez, J., Lloréns, M., Soler, A., Ortuño, J. F. (2002): Nutrient removal and sludge production in the coagulation-flocculation process. - Water Research 36: 29102919.

[2] APHA. (1995): Standard methods for the examination of water and wastewater. American Public Health Association, New York.

[3] AWWA. (1990): Water Quality and Treatment. - McGraw-Hill, New York.

[4] Aziz, H. A., Adlan, M. N., Zahari, M. S. M., Alias, S. (2004): Removal of ammoniacal nitrogen (N-NH3) from municipal solid waste leachate by using activated carbon and limestone. - Waste Management \& Research 22: 371-375.

[5] Benjamin, M. M., Sletten, R. S., Bailey, R. P., Bennett, T. (1996): Sorption and filtration of metals using iron-oxide-coated sand. - Water Research 30: 2609-2620.

[6] Celik, M. S., Ozdermir, B., Turan, M., Koyuncu, I., Atesok, G., Sarikaya, H. Z. (2001): Removal of ammonia by natural clay minerals using fixed and fluidized bed column reactors. - Water Supply 1: 81-99.

[7] Chapman, H. D. (1965): Cation-Exchange Capacity in Methods of Soil Analysis. - Series Agronomy Part 2: 891-900.

[8] Ehret, D. L., Alsanius, B., Wohanka, W., Menzies, J. G., Utkhede, R. (2001): Disinfestation of recirculating nutrient solutions in greenhouse horticulture. - Agronomie 21: 323-339.

[9] Ellis, K. V. (1987): Slow sand filtration as a technique for the tertiary treatment of municipal sewages. - Water Research 21: 403-410.

[10] Ellis, K. V., Wood, E. E. (1985): Slow sand filtration. - Crit. Rev. Environ. Contr., 15: 315-354.

[11] Farrah, S. R., Preston, D. R. (1985): Concentration of viruses from water by using cellulose filters modified by in situ precipitation of ferric and aluminum hydroxides. Applied and Environmental Microbiology 50: 1502-1504.

[12] Halim, A. A., Aziz, H. A., Johari, M. A. M., Ariffin, K. S. (2010): Comparison study of ammonia and COD adsorption on zeolite, activated carbon and composite materials in landfill leachate treatment. - Desalination 262: 31-35.

[13] Halim, A. A., Aziz, H. A., Johari, M. A. M., Ariffin, K. S., Bashir, M. J. K. (2012): Semiaerobic landfill leachate treatment using carbon-minerals composite adsorbent. Environmental Engineering Science 29: 306-312.

[14] Halim, A. A., Aziz, H. A., Megat Johari, M. A., Ariffin, K. S., Hung, Y. T. (2009): Removal of ammoniacal nitrogen and COD from semi-aerobic landfill leachate using 
low-cost activated carbon zeolite composite adsorbent. - International Journal of Environment and Waste Management 4: 399-411.

[15] Halim, A. A., Zainal Abidin, N. N., Awang, N., Ithnin, A., Othman, M S., Wahab, M. I. (2011): Ammonia and COD removal from synthetic leachate using rice husk composite adsorbent. - Journal of Urban Environmental Engineering 5: 24-31.

[16] Lei, L., Li, X., Zhang, X. (2008): Ammonium removal from aqueous solutions using microwave-treated natural Chinese zeolite. - Separation and Purification Technology 58: 359-366.

[17] Pearce, O., Clark, T., Ndombasi, P. (2000): Ammonnia Removal from Sludge Liquors. In: Thames Water Plc, Research and Technology Report.

[18] Rožić, M., Cerjan-Stefanović, Š., Kurajica, S., Vančina, V., Hodžić, E. (2000): Ammoniacal nitrogen removal from water by treatment with clays and zeolites. - Water Research 34: 3675-3681.

[19] Sarioglu, M. (2005): Removal of ammonium from municipal wastewater using natural Turkish (Dogantepe) zeolite. - Separation and Purification Technology 41: 1-11.

[20] Sivakumar, P., Palanisamy, P. N. (2009): Adsorptive removal of reactive and direct dyes using non-conventional adsorbent - column studies. - Journal of Scientific and Industrial Research 68: 894-899.

[21] Thomas, H. C. (1944): Heterogeneous ion exchange in a flowing system. - J. Am. Chem. Soc., 66: 1664-1666.

[22] Yoon, Y. H., Nelson, J. H. (1984): Application of gas adsorption kinetics I. A Theoretical Model for Respirator Cartridge Service Life. - American Industrial Hygiene Association Journal 45: 509-516. 